\title{
Observation of the Improvement in Nocturnal Asthma Symptoms with Administration of Once Daily Sustained Released Theophylline
}

\author{
Ruble MMK ${ }^{1}$, BariAKMR ${ }^{2}$, Biswas ${ }^{3}$, Anam MK ${ }^{4}$, Khuda ME ${ }^{5}$, Hossain MA $^{6}$, Kamal M$^{7}$
}

Conflict of Interest: None Received: $18-10-2017$

Accepted: 22-11-2017 www.banglajol.info/index.php/JSSMC

\begin{abstract}
:
Objective: The aims and objective of this study to observe the improvement in Nocturnal Asthma symptoms and Quality of Life (QoL) with administration of once daily sustained release theophylline preparation.

Background: Nocturnal symptoms are a common part of the asthma. Nocturnal asthma is defined by a drop in forced expiratory volume in 1 second (FEV1) of at least 15\% between bedtime and awakening in patients with clinical and physiologic evidence of asthma, which may include improvement in QoL.
\end{abstract}

\begin{abstract}
Methodology: The patient with Chronic Persistent Asthma, both sex, age >18 to 50 years of age and preferably patients with nocturnal exacerbations were included in the study. All patients were diagnosed on the basis of clinical history, physical examination, chest X-ray and pulmonary function tests, in accordance with the clinical criteria for the diagnosis by the GINA. The recruitment period was between March 2017 and August 2017 Shaheed Suhrawardy Medical College Hospital, Dhaka.
\end{abstract}

Results: It was observed that 65(92.85\%) was found exacerbation free night and 5(7.15\%) patients were found exacerbation with sustained release Theophylline. There are significantly improved qualities of life between $1^{\text {st }}$ follow up to $2^{\text {nd }}$ follow up, $3^{\text {rd }}$ follow up and $4^{\text {th }}$ follow up $p<0.001$ which was statistically significant. Spirometry test was gradually improved between $1^{\text {st }}$ visit of FEV1 to $2^{\text {nd }}, 3^{\text {rd }}$ and $4^{\text {th }}$ visit of FEV1, $(p<0.001)$ that was statistically significant.

Conclusion: Most of the patients were found exacerbation free night. There are significantly improved quality of life between $1^{\text {st }}$ follow up to $2^{\text {nd }}$ follow up, $3^{\text {rd }}$ follow up and $4^{\text {th }}$ follow up in Spirometry test. The value of FEV1 was gradually improve in the $l^{\text {st }}$ visit, $2^{\text {nd }}, 3^{\text {rd }}$ and $4^{\text {th }}$ visit with sustained release Theophylline.
Key Words:

FEV1, nocturnal

exacerbation, Asthma
[J Shaheed Suhrawardy Med Coll 2017; 9(2): 74-77] DOI: http://dx.doi.org/10.3329/jssmc.v9i2.37267
1. Md. Mesbahul Karim Ruble, Assistant Professor, Respiratory Medicine, ShaheedSuhrawardy Medical College, Sher-E-Bangla Nagar, Dhaka.

2. AKM Rafiqul Bari, Associate Professor, Respiratory Medicine, Shaheed Suhrawardy Medical College, Sher-E-Bangla Nagar, Dhaka.

3. Amar Biswas, Associate Professor, Respiratory Medicine, Shaheed Suhrawardy Medical College, Sher-E-Bangla Nagar, Dhaka.

4. Md. Khairul Anam, Associate Professor, Respiratory Medicine, Shaheed Suhrawardy Medical College, Sher-E-Bangla Nagar, Dhaka.

5. Mahbub-E-Khuda, Assistant Professor, Respiratory Medicine, National Institute of Diseases of the Chest \& Hospital, Mohakhali, Dhaka.

6. Md. Amjad Hossain, Assistant Professor, Medicine, Shaheed Suhrawardy Medical College, Sher-E-Bangla Nagar, Dhaka.

7. Mostofa Kamal, Junior Consultant, Medicine, Shaheed Suhrawardy Medical College, Sher-E-Bangla Nagar, Dhaka.

Address of correspondence: Dr. Md. MesbahulKarim Ruble, Assistant Professor (Respiratory Medicine), ShaheedSuhrawardy Medical College, Sher-E-Bangla Nagar, Dhaka. Cell: 01911134755, E-mail: mesbahulkarim@gmail.com

\section{Introduction}

Asthma is defined as a chronic inflammatory disorder of the airways which manifests itself as recurrent episodes of wheezing, breathlessness, chest tightness and cough. It is characterized by bronchial hyper responsiveness and variable airflow obstruction, that is often reversible either spontaneously or with treatment. ${ }^{1}$

Nocturnal asthma is defined by a drop in forced expiratory volume in 1 second (FEV1) of at least 15\% between bedtime and awakening in patients with clinical and physiologic evidence of asthma. Nocturnal asthma is associated with a circadian pattern in lung function, distal airway inflammation, glucocorticoid receptor affinity, pulmonary capillary blood volume, and beta- 2 adrenergic receptor function may also contribute. ${ }^{2}$ 
Nocturnal asthma is common and approximately 30 to 70 percent of patients with asthma report nocturnal asthma symptoms at least once a month. ${ }^{3,4}$ The occurrence of nocturnal asthma symptoms is also reflected in mortality statistics. As an example, over a one-year period, 53 percent of asthma deaths in one report occurred at night. ${ }^{5}$

As many as $75 \%$ of asthmatic subjects are awakened by asthma symptoms at least once per week, with approximately $40 \%$ experiencing nocturnal symptoms on a nightly basis. An extensive body of research has demonstrated that nocturnal symptoms of cough and dyspnea are accompanied by circadian variations- in airway inflammation and physiologic variables, including airflow limitation and airways hyper responsiveness. Nocturnal worsening of asthma is a well-described and important problem that must be considered in the management of patients with asthma ${ }^{6}$. In particular, nocturnal asthma symptoms are felt to be a characteristic feature of asthma that is not well-controlled ${ }^{7,8}$.

Increasing awareness of the exaggerated circadian rhythm in bronchomotor tone that causes most asthmatic patients to have increase respiratory symptoms in the early morning has resulted in a search for such a sustained release molecule with superior dosing strategy that will provide maximal bronchodialatory activity at the time of reduced bronchial patency.

\section{Objective of this Study}

The objective of this study to observe the improvement in Nocturnal Asthma symptoms and Quality of Life (QoL) with administration of once daily sustained release theophylline preparation.

\section{Materials and methods:}

Sample size: A total of 70 patients with choronic persistent asthma, both sex, age $>18$ to 50 years of age and preferably patients with nocturnal exacerbations were included in the study. March 2017 to August 2017 in Shaheed Suhrawardy Medical College Hospital, Dhaka.

Each patient underwent recording of medical, occupational, and smoking history; physical examination; chest radiography and spirometry as screening tests to ensure that they met the inclusion criteria. The spirometry was performed before and 20 minutes after inhalation of a bronchodilator at the first visit. Dyspnea was scored using the British MRC dyspnea scale (Moor-Jankowski 1976). Patients who met all the criteria were enrolled in study. The patients had been receiving sustained release of theophylline at evening. None of the patients was treated with anti-histamines, anti-leukotrienes, cromolyn, $\beta$ blockers, ACE inhibitors, oral prednisolone, and/or LABAs during the study. Some of the patients had discontinued these medications at least 4 weeks before enrollment. Patients were excluded if they had experienced an exacerbation within 4 weeks before enrollment. The use of a short-acting $\beta_{2}$-agonist or short-acting anticholinergic on demand was permitted. Physical examinations, spirometry, and MRC scoring, were performed at screening and baseline, and after 4 and 8 weeks of treatment.

\section{Results}

\section{Table-I}

Number of exacerbation free night

\begin{tabular}{lcc} 
& Number & Percentage \\
\hline Exacerbation free night & 65 & 92.86 \\
Number exacerbation & 05 & 7.14 \\
\hline Total & 70 & 100.00 \\
\hline
\end{tabular}

Regarding number of exacerbation free night, It was observed that $65(92.86 \%)$ was found exacerbation free night and 5(7.14\%) patients were found exacerbation.

Table-II

Number of undisturbed sleep at night on admission

Number of undisturbed Number Percentage
sleep at night of patients

\begin{tabular}{lcc}
\hline $1^{\text {st }}$ follow up & 36 & 51.43 \\
$2^{\text {nd }}-3^{\text {rd }}$ follow up & 29 & 41.43 \\
$3^{\text {rd }}-4^{\text {th }}$ follow up & 05 & 7.14 \\
\hline Total & 70 & 100.0 \\
\hline
\end{tabular}

It was observed that number of undisturbed sleep at night $36(51.43 \%)$ was found on $1^{\text {st }}$ follow up, $29(41.43 \%)$ was on $2^{\text {nd }}-3^{\text {rd }}$ visit and $05(7.14 \%)$ on the $3^{\text {rd }}-4^{\text {th }}$ visit.

Table-III

\begin{tabular}{|c|c|c|c|}
\hline \multicolumn{4}{|c|}{ Improved in FEVI } \\
\hline & MeaniSD & Mean \pm SD & $\mathrm{P}$ value \\
\hline 1st-FEV1-2 ${ }^{\text {nd }} F E V 1$ & $47.43( \pm 5.97)$ & $54.86( \pm 4.62)$ & 0.01 \\
\hline 1st-FEV1-3 ${ }^{\text {rd }} \mathrm{FEV} 1$ & $47.43( \pm 5.97)$ & $81.41( \pm 6.16)$ & $<0.001$ \\
\hline $1^{\text {st }}-F E V 1-4^{\text {th }} F E V 1$ & $47.43( \pm 5.97)$ & $85.50( \pm 5.79)$ & $<0.001$ \\
\hline
\end{tabular}

There were significantly improved FEV1 between 1 st follow up to 2 nd follow up, 3rd follow up and $4^{\text {th }}$ follow up. Here $\mathrm{p}<0.001$, which was statistically significant. 


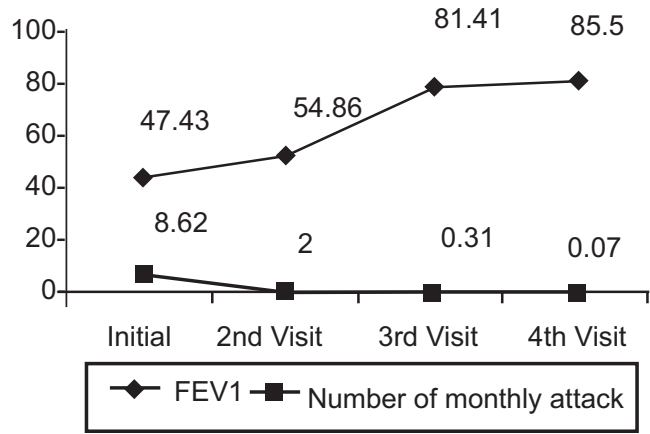

Fig.-1: Improved in quality of life

Table-IV

Mean changes in sipometry test

\begin{tabular}{|c|c|c|c|c|c|}
\hline \multirow[t]{2}{*}{$\begin{array}{l}\text { Changes in } \\
\text { Spirometry } \\
\text { Test }\end{array}$} & \multicolumn{5}{|c|}{$\begin{array}{l}95 \% \text { confidence } \\
\text { interval of the } \\
\text { difference }\end{array}$} \\
\hline & Mean & $+\mathrm{SD}$ & Lower & Upper & $<0.00$ \\
\hline 1st-FEV1 $-2^{\text {nd }} F E V 1$ & 7.43 & \pm 3.08 & 6.69 & 8.16 & $<0.00$ \\
\hline 1st-FEV1 $-3^{\text {rd }}$ FEV1 & 33.98 & \pm 9.30 & 31.76 & 36.20 & $<0.00$ \\
\hline $3^{\text {rd }}-\mathrm{FEV} 1-1 \mathrm{st}$ FEV 1 & 38.07 & \pm 8.92 & 35.94 & 40.20 & $<0.00$ \\
\hline $4^{\text {th }} F E V 1-2^{\text {nd }} F E V 1$ & 26.55 & \pm 8.15 & 34.61 & 28.50 & $<0.00$ \\
\hline $3^{\text {rd }}-F E V 1-2^{\text {nd }} F E V 1$ & 3064 & \pm 8.00 & 28.73 & 32.35 & $<0.00$ \\
\hline $4^{\text {th }} \mathrm{FEV} 1$ & & & & & \\
\hline
\end{tabular}

Regarding mean change in spirometry test, It was observed that spirometry test the value of FEVI was gradually improved in 12 st visit, $2^{\text {nd }}$ visit, $3^{\text {rd }}$ visit and $4^{\text {th }}$ visit $(p<0.001)$ that was statistically signficant.
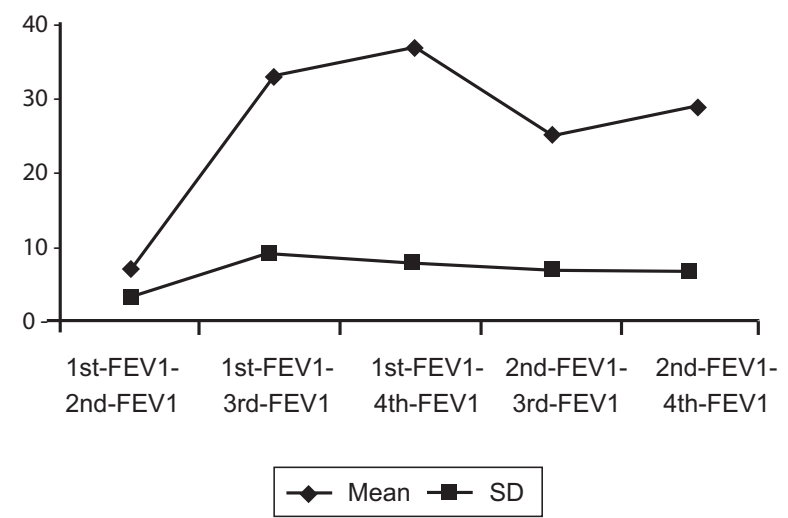

Fig.-2: Mean changes in spirometry test

\section{Discussion}

Regarding number of exacerbation free night, It was observed that $65(92.86 \%)$ was found exacerbation free night and $5(7.14 \%)$ patients were found exacerbation. Yiin $\mathrm{KT}$, et al. ${ }^{9}$ found that administration of Uniphyllin $(10 \mathrm{mg} /$ $\mathrm{kg}$ ) once a day at $6 \mathrm{PM}$ could maintain the blood level of theophylline within therapeutic range at least 12 to $24 \mathrm{hrs}$. The peak expiratory flow rate of the 6 cases we collected, were significantly improved.

It was observed that duration of undisturbed sleep at night $33(47.1 \%)$ was found $<3$ months, $26(37.1 \%)$ was between 4-5 months and $11(15.7 \%)$ was between 6 of months. Direct effects of sleep on breathing, such as changes in breathing pattern ${ }^{10}$ and ventilator control ${ }^{11,12}$ are transient and on arousal return to the patterns found in wakefulness.

There are significantly improved qualities of life between $1^{\text {st }}$ follow up to $2^{\text {nd }}$ follow up, $3^{\text {rd }}$ follow up and $4^{\text {th }}$ follow up $p<0.001$ which was statistically significant. Helm SG and Meltzer ${ }^{13}$ study found once-daily regimen of controlled release theophylline (Uniphyl tablets) with previous twice- or thrice-daily methylxanthine regimens. Three hundred asthmatic patients, 78 percent prone to nocturnal episodes during prior therapy, completed the investigation. Eighty-two percent of the patients were treated for moderate or severe disease. After a one-week evaluation of baseline theophylline therapy (with adjunctive medication), the patients substituted evening doses of the once-daily drug in approximate milligram-for milligram equivalent doses. Concomitant medications were allowed as before. Nighttime and morning asthma control improved significantly without deterioration in the evening, and without increased side effects. Once daily therapy resulted in markedly fewer night awakenings involving inhaler use $(p<0.01)$ and near 60 percent reductions in the number of patients with night time or early morning exacerbations $(\mathrm{p}<0.01)$ Control of morning chest tightness, wheeze, and dyspnea Improved significantly $(p<0.01)$ and patients' as well as investigators' global evaluations favored once-daily treatment $(p<0.01)$ Morning peak expiratory flow rates improved both at home $(\mathrm{p}<0.01)$ and at the office $(\mathrm{p}=$ 0.05 ). The forced expiratory volume in one second at the office increased modestly in the entire group. It is concluded that Uniphyl is effective and well tolerated when administered in once-daily evening doses.

FEV1 measurements in patients treated with theophylline were significantly improved compared with those observed in patients treated with placebo at treatment week 8 and week $12(p=0.004)$; these changes represented 8 and $16 \%$ improvements from baseline with placebo and theophylline, respectively, at week 12. Janson et al. ${ }^{14}$ a decrease in estimated sleep time (P less than 0.05) and increase in nocturnal wakefulness (P less than 0.05 ) was seen with decreasing daytime FEV1 - measured as 
percentage of the predicted value $(\% \mathrm{FEV} 1)$. There was also significant correlation between increasing age and decreasing \% FEV I (P less than 0.01). Kawayama et al. ${ }^{15}$ study observed that FEV I in the combinationgroup, but not in the theophylline alone, was significantly increased at $4(1.56 \pm 0.13 \mathrm{~L}, \mathrm{p}<0.001)$ and 8 weeks $(1.60 \pm 0.13 \mathrm{~L}, \mathrm{p}$ $<0.001)$ from the baseline $(1.40 \pm 0.12 \mathrm{~L})$. In the combination group, but not the theophylline alone group, the dyspnea score was significantly improved after $4(\mathrm{p}<0.01)$ and 8 weeks $(\mathrm{p}<0.05)$ compared with baseline.

\section{Conclusion}

Most of the patients were found exacerbation free night with sustained release theophylline. There was significantly improved quality of life between $1^{\text {st }}$ follow up to $2^{\text {nd }}$ follow up, $3^{\text {rd }}$ follow up and $4^{\text {th }}$ follow up. The value of FEV1 $3^{\text {rd }}$ was gradually improved in 1 st visit to $2^{\text {nd }}$ visit, $3^{\text {rd }}$ visit and $4^{\text {th }}$ visit. $p<0.001$ that was statistically singnificant

\section{References}

1. Felemban HS, Motahar AJ, Alzamzami NM, Felemban WA, Adnan AM, Albishi SS. Causes and Management of Asthma. The EgyptianJournal of Hospital Medicine 2018; 70: 76-81. Xiongbin J. Nocturnal Asthma: A Special Type of Asthma. Glob J Allergy 2016; 2(1): 3-9.

3. Storms WW, Bodman SF, Nathan RA, Byer P. Nocturnal asthma symptoms may be more prevalent than we think. J Asthma 1994; 31: 313- 318

4. Fagnano M, Bayer AL, Isensee CA, Hernandez T,1-lalterman JS, et al. Nocturnal asthma symptoms and poor sleep quality among urban schoolchildren with asthma.AcadPediatr 2011; 11: 493-499.
5. Robertson CF,Rubinfeld AR, Bowes G. Deaths from asthma in Victoria: a 12-month survey. Med J Aust1990; 152: 511517

6. Turner-Warwick M. Epidemiology of nocturnal asthma. Am J Med 1988; 85: 6-8.

7. NationalAsthma, Education and Prevention Program Expert panel report III. Guidelines for the diagnosis and management of asthma,Bethesda, MD: National Heart, Lung, and Blood Institute. 2007(NIH publication no. 08-4051)

8. Global Initiative for Asthma (GINA). Global Strategy for Asthma Management and Prevention.2015: 1-149.

9. Yiin KT, Chiang CD, Shill WL, Huang WL, JihKS, Lin TM, et al Sustained-release theophylline-uniphyllin in nocturnal asthmatics.Zhonghua Yi XueZaZhi(Taipei). 1989 Jan;43(I):43-8.

10. Douglas NJ, White DP, Pickett CK, et al. Respiration during sleep in normal man. Thorax 1982; 37: 840-4

11. Douglas NJ, White DP, Weil JV, et al. Hypoxic ventilator response decreases during sleep in normal men. Am Rev Respir Dis 1982; 125: 286-9

12. Douglas NJ, White DP, Weil IV, et al. Hypercapnicventilatory response in sleeping adults. Am Rev Respir Dis 1982; 126: 758-62

13. Helm SG and Meltzer SM, Improved Control of Asthma in the Office Setting a Large-Scale Study of Once-Daily Evening Doses of Theophylline. The American Journal of Medicine] 988; 85(suppl I B):30-33

14. Janson C, Gislason T, Boman G, Hetta J, RoosBE. Sleep disturbances in patients with asthma. Respir Med. 1990; 84(1): $37-42$.

15. Kawayama T, Tomoaki Hoshino T, Ichiki M, Tsuda T, Kinoshita M, Takata S, and Koga T. Effect of add-on therapy of tiotropium in COPD treated with theophylline. International Journal of COPD 2008:3(1) 137-147 